\title{
The CT Prevalence of Arrested Pneumatization of the Sphenoid Sinus in Patients with Sickle Cell Disease
}

\author{
(10)A.V. Prabhu and $\mathbb{1}_{\text {B.F. Branstetter IV }}$
}

\begin{abstract}
BACKGROUND AND PURPOSE: Arrested sphenoid pneumatization is an incidental radiologic finding on CT and MR imaging that may be confused with more aggressive pathologic conditions. No definite etiology for arrested sphenoid pneumatization has been established, though changes in regional blood flow during childhood, as is seen with sickle cell disease, have been proposed. The purpose of our study was to compare the prevalence of arrested pneumatization of the sphenoid sinus in patients with and without sickle cell disease.
\end{abstract}

MATERIALS AND METHODS: We retrospectively identified 146 patients with sickle cell disease who had undergone CT scans of the skull base between January 1990 and May 2015. We identified 292 control patients without sickle cell disease matched for age and sex in a 1:2 ratio. We tabulated the prevalence of arrested pneumatization as well as the location and size of the lesions. We used the Fisher exact test to correlate sickle cell disease with arrested pneumatization of the sphenoid sinus and the $t$ test to correlate sickle cell disease with lesion size.

RESULTS: Of the 146 patients with sickle cell disease, 14 (9.6\%) had arrested pneumatization of the sphenoid sinus. In the 292 control patients, $6(2.1 \%)$ had arrested pneumatization. Patients with sickle cell disease had a statistically significant higher rate of arrested pneumatization compared with patients without sickle cell disease $(P<.001)$. There was no statistically significant correlation between lesion size and diagnosis of sickle cell disease.

CONCLUSIONS: Patients with sickle cell disease have a greater prevalence of arrested pneumatization of the sphenoid sinus than patients without sickle cell disease. This supports the theory that either regional blood flow anomalies or increased serum erythropoietin causes arrested sinus pneumatization.

ABBREVIATION: SCD $=$ sickle cell disease

$\mathrm{T}$ he normal development of the sphenoid sinus is preceded by a phase of fatty transformation and fat involution in the bone marrow, followed by aeration of the marrow that then results in full pneumatization. ${ }^{1,2}$ This process begins at 4 months of age and usually ends at 10-14 years of age. ${ }^{3,4}$ This process may be interrupted, leaving atypical fatty marrow that persists into adulthood.

Change in regional blood flow has been suggested as a potential stimulus for fatty marrow conversion. ${ }^{5}$ If this theory is correct, then diseases that produce aberrant regional blood flow might predispose a person to arrested sinus pneumatization. Sickle cell disease (SCD) is an example of a disorder that produces regional blood flow changes in childhood, but no study has investigated

Received December 20, 2015; accepted after revision March 4, 2016.

From the Departments of Radiology (A.V.P., B.F.B.) and Otolaryngology (B.F.B.), University of Pittsburgh School of Medicine, Pittsburgh, Pennsylvania.

Please address correspondence to Arpan V. Prabhu, B.S., Department of Radiology, University of Pittsburgh School of Medicine, 200 Lothrop St, Pittsburgh, PA 15213;

e-mail: prabhuav2@upmc.edu

http://dx.doi.org/10.3174/ajnr.A4801

the correlation between arrested sphenoid pneumatization and SCD.

We hypothesized that there is an increased prevalence of arrested pneumatization of the sphenoid sinus in patients with SCD compared with those without SCD.

\section{MATERIALS AND METHODS Study Participants}

The institutional review board at the University of Pittsburgh Medical Center approved this retrospective study of existing imaging data, and written consent was waived. We retrospectively searched our electronic medical records to identify CT scans of the face, orbit, sinuses, and temporal bones obtained between January 1990 and May 2015, each performed on a different patient at least 1 year of age.

We identified 146 patients with SCD (cohort group) and then identified 292 patients from the same date range without SCD (control group) matched for age and sex at a 1:2 ratio. The diagnosis of SCD was confirmed with genetic testing for every patient in the cohort group. Patients were excluded if they had undergone 

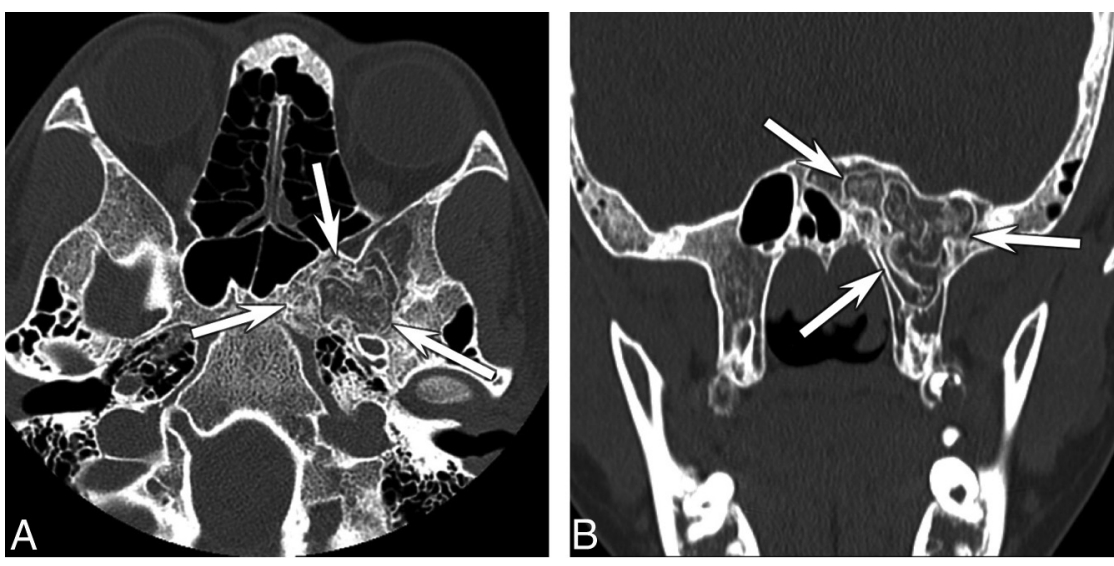

FIGURE. Axial $(A)$ and sagittal $(B)$ contrast-enhanced $C T$ images show a nonexpansile lesion (arrows) located at a normal left sphenoid sinus pneumatization site with a thin cortical margin, internal fatty content, and curvilinear internal calcifications. This is the characteristic appearance and location for arrested pneumatization of the sphenoid sinus.

Table 1: Frequency and size of sphenoid fibro-osseous lesions visualized on head CT

\begin{tabular}{lcc}
\hline \multicolumn{1}{c}{ Group } & Frequency (\%) & Size $^{\mathrm{a}} \pm$ SD (mm) \\
\hline SCD $(n=146)$ & $14(9.6 \%)$ & $14.3 \pm 10.2$ \\
Control $(n=292)$ & $6(2.1 \%)$ & $8.85 \pm 5.6$ \\
\hline
\end{tabular}

${ }^{a}$ Size is the maximal axial dimension. There was a statistically significant relationship $(P<.001)$ between presence of SCD and frequency of sphenoid fibro-osseous lesions. There was no statistically significant relationship between lesion size and SCD status $(P=.24)$.

Table 2: Location of sphenoid fibro-osseous lesions in patients with and without SCD

\begin{tabular}{|c|c|c|c|}
\hline \multirow[b]{2}{*}{ Location } & \multicolumn{2}{|c|}{ Frequency } & \multirow[b]{2}{*}{$\begin{array}{c}\text { Total } \\
\text { Frequency }\end{array}$} \\
\hline & $\begin{array}{c}\text { Patients } \\
\text { with } \\
\text { SCD }^{\mathrm{a}}\end{array}$ & $\begin{array}{c}\text { Patients } \\
\text { without } \\
S C^{a}\end{array}$ & \\
\hline Left greater sphenoid wing & $7(50)$ & $4(67)$ & $11(55)$ \\
\hline Right greater sphenoid wing & $3(21)$ & $2(33)$ & $5(25)$ \\
\hline Bilateral sphenoid wings & $4(29)$ & $0(0)$ & $4(20)$ \\
\hline Total & $14(70)$ & $6(30)$ & $20(100)$ \\
\hline
\end{tabular}

${ }^{a}$ Data presented as number of patients (\%).

surgery or radiation to the skull base, if the scans demonstrated skull base pathology, if there was inadequate scan coverage of the skull base, or if streak artifact prevented clear evaluation of the region of the sphenoid sinuses.

\section{Imaging}

CT was performed on a 64-channel scanner (VCT, HD, and Optima LightSpeed systems; GE Healthcare, Milwaukee, Wisconsin) with variable $\mathrm{mA}, \mathrm{kVP}$ of 120 , section thickness reconstructed at $1.25 \mathrm{~mm}$, and section spacing of either $1.25 \mathrm{~mm}$ or $0.625 \mathrm{~mm}$. Display field of view varied with patient size but was approximately $25 \mathrm{~mm}$. Coronal and sagittal reformatted images were routinely obtained but were not used in this evaluation.

Each examination was evaluated in random order by a medical student trained to identify sphenoid lesions. The medical student intentionally interpreted the examinations with very high sensitivity so that no true lesions would be overlooked. Each case with a possible lesion was then re-evaluated by a fellowship-trained neuroradiologist with Certificate of Added Qualification in neuroradiology and 13 years of dedicated experience in head and neck imaging. The location of the lesion and greatest axial length were recorded. Both observers were blinded to the clinical history of the patient and the SCD status.

Using guidelines from Welker et al, ${ }^{6}$ arrested pneumatization was defined on $\mathrm{CT}$ as a nonexpansile lesion located at a normal sphenoid sinus pneumatization site with a thin cortical margin, internal fatty content, and curvilinear internal calcifications (Figure). The lesion must respect the margins of adjacent neural foramina and lack a normal trabecular pattern.

\section{Statistical Tests}

The percentage of patients with arrested sphenoid pneumatization in each group was tabulated. The Fisher exact test was used to determine correlation between a diagnosis of SCD and arrested pneumatization of the sphenoid sinus. The test was 2-sided, and a $P$ value of .05 was chosen as the threshold for statistical significance. A $t$ test was used to determine any relationship between a diagnosis of SCD and maximum axial dimension of the sphenoid lesions, again by using a $P$-value threshold of .05 .

\section{RESULTS}

The 146 patients in the cohort group included 58 male (39.7\%) and 88 female patients $(60.3 \%)$, with a median age of 30 years (mean, 35.0 years; range, $1-100$ years). Of the 146 patients, 5 (3\%) were $1-4$ years old, and 15 (10\%) were 5-14 years old. The same demographic percentages applied to the matched control group.

Of the 146 patients with SCD, 14 (9.6\%) had arrested pneumatization of the sphenoid sinus. In the 292 control patients, 6 $(2.1 \%)$ had arrested pneumatization $(P<.001)$. The size of the lesions (mean $\pm \mathrm{SD}$ ) was $14.3 \pm 10.2 \mathrm{~mm}$ in patients with SCD and $8.85 \pm 5.6 \mathrm{~mm}$ in patients without SCD (Table 1 ). The most frequent location of the lesions was the left greater wing of the sphenoid bone ( 11 of 20 patients, 55\%) (Table 2).

A Fisher exact test demonstrated that patients with SCD had a statistically significant higher rate of arrested pneumatization compared with patients without SCD $(P<.001)$. A $t$ test showed no significant relationship between a diagnosis of SCD and the size of the lesions $(P=.24)$.

\section{DISCUSSION}

The normal pneumatization process of the sphenoid sinus begins after birth and usually ends at 10-14 years of age with the formation of a fully pneumatized sinus lined by respiratory epithelium. ${ }^{3,4}$ This process can be interrupted for unclear reasons, especially in the sphenoid sinus. The most familiar etiology is chronic inflammation, as seen in patients with cystic fibrosis, ${ }^{7-9}$ but other factors can produce a similar result. It is also unclear why arrested pneumatization has been shown to occur most often in the sphenoid sinuses, though it may be because of greater variation in the extent of aeration in the sphenoid sinus compared 
with other paranasal sinuses. ${ }^{6}$ Regarding arrested pneumatization, there is a theory that aeration triggers the fatty marrow conversion in the sphenoid sinus, ${ }^{1}$ whereas another theory suggests that the ratio of trabecular to cortical bone is the driving mechanism. ${ }^{10}$ Yonestu et $\mathrm{al}^{5}$ suggested a subsequent theory of regional blood flow changes as the reason for atypical fatty marrow that persists into adulthood.

It is important to note that the theory of regional blood flow has not been proved. Using MR signal intensity changes on T1WI, Yonetsu et al ${ }^{5}$ showed sphenoid marrow conversion before 1 year of age, when aeration of the sphenoid bone does not occur. ${ }^{4,11}$ This suggested that factors other than air supply, such as blood supply, play an important role in conversion of the marrow. ${ }^{5}$ Humoral factors also may play a role in arrested pneumatization of the sphenoid sinus, considering that serum erythropoietin levels have been shown to be elevated in patients with SCD. ${ }^{12}$ The elevated erythropoietin may interrupt the conversion of hematopoietic to fatty marrow.

The phrase "arrested pneumatization" makes an assumption about the etiology of the sphenoid lesions that has not been proved. In fact, radiologists may be uncomfortable using the phrase because it is only one of several theories for the etiology of these fibro-osseous lesions. Our study supports this terminology and the theory of regional blood flow anomalies or increased serum erythropoietin as a potential cause of arrested sinus pneumatization.

The differential diagnosis for a mass in a normal sphenoid sinus pneumatization site includes fibrous dysplasia, clival chordoma, chondrosarcoma, intraosseous lipoma, intraosseous hemangioma, hamartoma, ossifying fibroma, enchondroma, and fibrous osteoma. ${ }^{6,13-16}$ Arrested pneumatization may be distinguished from these entities as a nonexpansile lesion with a thin cortical margin, internal fatty content, and curvilinear internal calcifications (Figure). ${ }^{6}$ These calcifications differ from the "ring and arc" calcifications seen with chondroid tumors. ${ }^{13}$ Intraosseous lipomas share some imaging characteristics with arrested sinus pneumatization, ${ }^{14}$ leading to the theory that these entities are of similar etiology. However, our findings do not support this theory. In particular, arrested pneumatization should not be confused with ossifying fibroma. Whereas the internal matrix of arrested pneumatization is characterized by curvilinear calcification and fatty contents, ossifying fibromas exhibit ground-glass marrow on CT, often with an overlying radial pattern of calcification. ${ }^{17}$ Ossifying fibromas are also expansile and may be exophytic into the sinus itself. ${ }^{18}$

Our study has some important limitations. The study was retrospective, and all the patients in the study were imaged for various clinical reasons. The number of patients was too small to break down our results by age to determine when these lesions formed and determine whether age is predictive of prevalence. Although the control patients were matched for age and sex, patient race was not reliably available to us, so we could not account for this potential confounder. Serial CT scans could provide more information about the usual development of arrested sphenoid pneumatization, but in our series, no patients with lesions had serial scans. Although the total number of patients in our series who had arrested pneumatization was small, the statistical results comparing the 2 groups were robust, with a $P$ value less than .001 .

Our study included some patients younger than 14 years of age, when the development of the sphenoid sinuses is still ongoing. Although these patients may be less likely to have fibro-osseous lesions, we felt justified to include these patients because 2 patients with SCD (ages 8 and 14 years) had evidence of arrested sphenoid pneumatization. Additionally, the case-control format of our study would prevent this from biasing our overall results.

\section{CONCLUSIONS}

Patients with SCD exhibit a higher prevalence of arrested pneumatization of the sphenoid sinus than patients without SCD. This supports the theories that either regional blood flow anomalies or increased serum erythropoietin cause arrested sinus pneumatization and supports the continued use of this terminology.

\section{ACKNOWLEDGMENTS}

The authors thank Rose Jarosz for her role as research coordinator for this study.

Disclosures: Arpan V. Prabhu—RELATED: Grant: University of Pittsburgh School of Medicine through the Dean's Summer Research Program.

\section{REFERENCES}

1. Aoki S, Dillon WP, Barkovich AJ, et al. Marrow conversion before pneumatization of the sphenoid sinus: assessment with MR imaging. Radiology 1989;172:373-75 CrossRef Medline

2. Scuderi AJ, Harnsberger HR, Boyer RS. Pneumatization of the paranasal sinuses: normal features of importance to the accurate interpretation of CT scans and MR images. AJR Am J Roentgenol 1993; 160:1101-04 CrossRef Medline

3. Jang YJ, Kim SC. Pneumatization of the sphenoid sinus in children evaluated by magnetic resonance imaging. Am J Rhinol 2000;14: 181-85 CrossRef Medline

4. Szolar D, Preidler K, Ranner G, et al. Magnetic resonance assessment of age-related development of the sphenoid sinus. Br J Radiol 1994; 67:431-35 CrossRef Medline

5. Yonetsu K, Watanabe M, Nakamura T. Age-related expansion and reduction in aeration of the sphenoid sinus: volume assessment by helical CT scanning. AJNR Am J Neuroradiol 2000;21:179-82 Medline

6. Welker KM, DeLone DR, Lane JI, et al. Arrested pneumatization of the skull base: imaging characteristics. AJR Am J Roentgenol 2008; 190:1691-96 CrossRef Medline

7. Bonfield TL, Konstan MW, Berger M. Altered respiratory epithelial cell cytokine production in cystic fibrosis. J Allergy Clin Immunol 1999;104:72-78 CrossRef Medline

8. Chmiel JF, Berger M, Konstan MW. The role of inflammation in the pathophysiology of CF lung disease. Clin Rev Allergy Immunol 2002; 23:5-27 CrossRef Medline

9. Nichols D, Chmiel J, Berger M. Chronic inflammation in the cystic fibrosis lung: alterations in inter- and intracellular signaling. Clin Rev Allergy Immunol 2008;34:146-62 CrossRef Medline

10. Gurevitch O, Slavin S, Feldman AG. Conversion of red bone marrow into yellow - cause and mechanisms. Med Hypotheses 2007;69: 531-36 CrossRef Medline

11. Madeline LA, Elster AD. Suture closure in the human chondrocranium: CT assessment. Radiology 1995;196:747-56 CrossRef Medline

12. Ballas SK, Marcolina MJ. Determinants of red cell survival and erythropoietic activity in patients with sickle cell anemia in the steady state. Hemoglobin 2000;24:277-86 CrossRef Medline 
13. Weerakkody Y. Arrested pneumatisation of the skull base (sphenoid sinus). EuroRad 2013; Case 10648 CrossRef

14. Jalali E, Tadinada A. Arrested pneumatization of the sphenoid sinus mimicking intraosseous lesions of the skull base. Imaging Sci Dent 2015;45:67-72 CrossRef Medline

15. Politi M, Romeike BF, Papanagiotou P, et al. Intraosseous hemangioma of the skull with dural tail sign: radiologic features with pathologic correlation. AJNR Am J Neuroradiol 2005;26:2049-52 Medline
16. Srubiski A, Csillag A, Timperley D, et al. Radiological features of the intraosseous lipoma of the sphenoid. Otolaryngol Head Neck Surg 2011;144:617-22 CrossRef Medline

17. Baumann I, Zimmermann R, Dammann F, et al. Ossifying fibroma of the ethmoid involving the orbit and the skull base. Otolaryngol Head Neck Surg 2005;133:158-59 CrossRef Medline

18. Eversole R, Su L, ElMofty S. Benign fibro-osseous lesions of the craniofacial complex. A review. Head Neck Pathol 2008;2:177-202 CrossRef Medline 